\title{
The Psychosocial Impact of the Romanian Government Measures on the Population During the COVID-19 Pandemic
}

\author{
Armenia Androniceanu \\ Bucharest University of Economic Studies, Faculty of Administration and Public \\ Management, Romania \\ University of Social Sciences, Lodz, Poland \\ armenia.androniceanu@man.ase.ro \\ https://orcid.org/0000-0001-7307-5597 \\ Doina-Mihaela Marton \\ Bucharest University of Economic Studies, Faculty of Administration and Public \\ Management, Romania \\ marton.doinamihaela@gmail.com \\ https://orcid.org/0000-0002-5908-4224
}

Received: 24. 2. 2021

Accepted: 1. 4. 2021

\section{ABSTRACT}

The Covid-19 pandemic generated a global crisis involving most countries in the world. State governments worldwide were forced to take appropriate measures impacting different fields. The Romanian government and other local public authorities developed special measures to curb the spread of the SARS-COV-2 virus in Romania in general and in Bucharest, the country's capital. The purpose of our research was to identify the social and psychological impact of the governmental measures on the citizens of Bucharest. The research was conducted between 28 November and 25 December 2020, but refers to the measures taken by the government and local authorities from the onset of the Covid-19 pandemic to date. The sample, representative for Bucharest, included 421 citizens living in Bucharest, aged between 19 and 40 years. The data were collected using an online questionnaire. Other methods used to analyse the results and verify the hypothesis included the multiple regression model and some applications in Excel. The results confirmed that governmental measures had a strong social and psychological impact on citizens, changing their social behaviour and causing psychological disorders, such as depression and anxiety. Our research results can help the Romanian authorities avoid problems among the population and adapt their measures to better meet the population's psychosocial needs in time of the Covid-19 pandemic crisis, which is far from over.

Keywords: Covid-19, governmental policy, social impact, pandemic, psychological impact

JEL: $/ 12,118$ 


\section{Introduction}

Pandemics occur from time to time in society, causing the death of millions of people (Akas and Karataş, 2020, p. 3) and they can cause frustration, anxiety, depression or fear (Ballou et al., 2020, p. 2). Most pandemics so far have a major social, economic and psychological impact on humanity and are characterized by a widespread geographical extension (Morens et al., 2009, p. 1020; Besenyő and Kármán, 2020, p. 631; Chehabeddine and Tvaronavičienè, 2020, p. 432; Davulis et al., 2021, p.310). The same factors were studied by Mura and Horváth (2015, p. 867). Now, the COVID-19 pandemic has had an unprecedented impact on the daily life of the population all around the world. The measures adopted by the governments of the affected states have led to significant changes in the population's behavior, having a major impact on both the mental and physical health of the citizens. First discovered in Wuhan, China, the SARS-CoV-2 virus spread at a very high rate on a worldwide scale, leading this way to the COVID-19 Pandemic (Zandi et al., 2020, pp. 1-2). Some symptoms of COVID-19 are fever, dry cough, loss of taste or smell (World Health Organization, 2020). According to the World Health Organization (WHO), until the 31st of January 2021, there were 101,917,147 confirmed cases and 2,205,515 confirmed deaths of SARS-CoV-2 worldwide (World Health Organization, 2021).

Facing this global crisis, the public authorities from every state had to issue new sets of measures in order to limit the spread of the SARS-CoV-2 virus. Among the adopted measures there are: wearing of a protective mask, isolation, quarantine and social distancing. In China, for example, strict measures have had an impact on reducing the transmission of the SARS-CoV-2 virus (Liu et al., 2020, p. 77). 'The normal' life which the population was used to have, suffered a drastic change, people's lifestyle and behavior have been strongly affected.

The adopted measures also had an impact in Romania over the mental and physical health of the population. Thereby, the scope of this research was to identify the social and the psychological impact of the measures adopted by the Romanian Government and the local authorities on Bucharest's citizens. Our research question is: Which were the social and psychological effects of the governmental measures on the population aged between 19 and 40 in Bucharest in the first nine months of the pandemic?

It is necessary to specify that some governmental measures from different states, including Romania, were influenced by the recommendations communicated by the European institutions and by the World Health Organization which were actively involved in managing this crisis ever since its outbreak. Also, the European Union has been actively involved in this situation, encouraging states to do more tests (Androniceanu, 2020, p. 144). The measures formulated by the national and local state authorities should be analyzed by them and by the researchers, too, because they produce long-term consequences over the mental, social and physical health of the population. The aftermath of the current sanitary crisis could affect the following crises that may emerge, given the fact that because of the responses and the obtained 
effects it can be determined what was helpful and whatnot. This aspect itlustrates the importance of studying the impact of WHO's recommendations and local governments' politics and endorsed measures because it can help towards the improvement of the organization and the functionality of the administrative systems all around the world.

\section{Literature review}

Being an ongoing issue, the COVID-19 pandemic and the impact of the adopted measures on the people represent significant subjects which were addressed by researchers, government official and population globally (Silva Junior et al., 2020, p. 2; Carrasco Sierra et al., 2020, p. 1). The effects can already be seen and they will continue to be more and more obvious, in time, on a world scale. The negative effects are not limited to the psychological ones, the other effects such as social, economic, political effects being already seen in many states (Arpaci et al., 2020, p. 1; Dobrowolski, 2020, p. 800; Moyo, 2020, p. 329). Different international researchers pointed out that social isolation, anxiety or stress contribute to the appearance or even aggravation of some disorders and changes in people's behavior (Rathod et al., 2020, p. 6). They become more depressed and they can commit suicide. USA, Great Britain, Italy or Germany are some of the states that reported suicides caused by the fear of the SARS-CoV-2 virus (Sher, 2020, pp. 707-712). Also, Akat and Karataş (2020, p. 4) mentioned that, even if all people feel the psychological effects of the COVID-19 pandemic, the strongest psychological effects are felt by people who have been infected with the SARS-CoV-2 virus. Hu et al. (2020, pp. 1-18) demonstrated that schizophrenia (3,541 people), depressive episodes (3,230 people) and other anxiety disorders (1,284 people) are the first three psychological effects on the people who participated in a study conducted in China during 2020. People's lives have been affected by this crisis caused by the COVID-19 pandemic and fear, anxiety or stress are some of its fallouts. To overcome this situation, the efforts of the public authorities and those of the people should be better coordinated. The public authorithies have to adopt measures and people have to respect them. The approach by which the government decides on the measures and the way the population applies these measures has proved to be inappropriate in many European countries and beyond. Excellent communication and effective coordination of the implementation process have been needed. If there is no effective coordination, the measures are taken in vain (Singh et al., 2020, pp. 168-172). In addition, the closing of schools and universities has a long-term impact on kids and students because these actions reduced their ability to learn and the capacity to develop minimal skills and competences (Amiri et al., 2020; Sawangchai et al., 2020, pp. 503-505). At the same time, this measure reduced the quality of the educational process because most of the states have implemented an online education system, a measure that was not efficient in many of them.

According to our research, there should be a public consultation on the measures taken by governments during the pandemic (Nosková and Peráček, 2019, 
p. 48). Governments should clearly communicate the measures and explain their content in order to be successful in this context. Governments and doctors need to explain clearly and coherently why certain government measures restricting their freedoms should be accepted and respected. Some measures adopted in different states were related to the treatment schemes. Some measures taken in some states were for certain drugs, which were changed along the way because they were not enough or not effective in fighting the SARS-CoV 2. Bo et al. (2020, pp. 1-2) demonstrated that the people who were infected with the SARS-CoV-2 virus showed symptoms of post-traumatic stress even before they were discharged from the hospital. So, monitoring the psychological consequences should become a global habit (Huang and Zhao, 2020, p. 5). This situation generates negative effects on other people. For the longterm, it is necessary to monitor and check the psychological evolution of the people who overcame COVID-19 (Zandi et al., 2020, p. 2). It is necessary to follow three steps in order to minimize the psychological effects of the COVID-19 pandemic. The first step refers to the fact that mental health professionals should not be assigned to work in other medical areas. The second step refers to some measures, such as targeted psychological interventions for communities affected by COVID-19 or improved access to psychological interventions (especially online). The third step refers to paying special attention to people who are on the frontline against the SARS-CoV-2 virus (Cullen et al., 2020, pp. 311-312). In addition, in this period, people are using the social media platforms more than ever. Arpaci et al. (2020, pp. 193-204) performed research between $22^{\text {nd }}-30^{\text {th }}$ of March 2020 and analyzed over 43 million posts on Twitter. Among the most used words on Twitter are 'death', 'spread', 'lockdown', and this shows that the people are afraid of both the spread of the virus and the idea of a lockdown, issues that limit the population's mobility and freedom.

The human race is social by nature and social interaction represents a part of human civilization (Belas et al., 2020, p. 133; Vlacseková and Mura, 2017, p. 126; Korauš et al., 2020, p. 39). In order not to be infected or not to transmit the virus to the community, the physical distancing is a measure that determines people to work from home and avoid other people or social contacts. These changes shifted the typical 'normality' to which people were accustomed and their social relationships suffered, affecting their psychological and psychosocial states (Naser et al., 2020, p. 1). The absence of these social interactions can provoke and amplify anxiety, loneliness, depression and these effects influence not only the individual, but also the society as a whole (Singh et al., 2020, pp. 168-172). Physical distancing is a new concept that determined people to develop new habits and to realize that their survival needs are very limited and a new approach to their interactions with their family or friends is needed (Verma and Prakash, 2020, pp. 7352-7363).

To understand the positive or negative social impact of the pandemic, we should first identify it. During the pandemic time, people can spend a lot of time with their families and this is, obviously, an advantage created by this pandemic. However, in some states, including Romania, the number of divorces has increased, the number of marriages has decreased and cases of 
conflict between family members have also increased. Before the COVID-19 pandemic, people were so busy with their jobs so that they did not have time to satisfy their own hobbies. As a result of the measures adopted in the context of COVID-19, a lot of economical areas have suffered, many of them being closed and these put them at a disadvantage because people have to live with the idea that they do not have a job and they do not earn money to live their everyday life (Amiri et al., 2020). However, people have a lot of free time now and they can use it to satisfy their hobbies or to do different activities for which they could not allocate enough time before. In addition, closing some areas help the environment to recover, given the fact that the pollution has decreased significantly. Families and couples spend more time together, but for some people this action can be a disadvantage because in some cases can appear domestic violence and in other cases, it can be amplified. A part of the people infected with the SARS-CoV-2 virus need hospitalization, so many hospitals from different cities and regions changed their activity and became main hospitals or support hospitals for COVID-19. Given the fact that currently the priority of the hospitals is treating people with COVID-19, people who have an emergency and they need hospitalization or people who have some health problems which can only be solved in the hospital, they may not receive the necessary health service, they can be neglected, and this is certainly a disadvantage created by this pandemic (Haleem et al., 2020, p. 1; Vidyakant and Appasani, 2020).

\section{Research methodology}

The research process went through several stages. In the first stage, we studied the literature about COVID-19. In the second stage, we established the purpose, the specific objectives, the hypothesis and the variables of the research. The purpose of the research was to identify the impact of the measures adopted by the Romanian Government and local authorities on citizens aged between 19 and 40 years, resident in Bucharest.

The main specific objectives of our research were the following: (1) to identify the most relevant measures issued by the authorities, which had an impact over the targeted citizens; (2) to identify the main social and psychological effects determined by the adopted measures; (3) to identify the main activities which helped the population to adapt to the enforced measures; (4) to identify the behavior changes as a result of the endorsed measures; (5) to identify the measures according to the citizen's opinions that could have reduced negative social and psychological impact on the population.

The research had four hypotheses: (1): If the targeted citizens had been consulted regarding the measures adopted to limit the spread of SARS-CoV-2 virus, then they would have complied more with the administrative measures; (2) The citizens' belief that closing the restaurants, terraces and cafes during the alert state had a strong psychological and social impact on them, which was stronger compared to those who felt affected by the measure that involved maintaining physical distance; (3) If the targeted citizens were alone 
during the emergency stage, then they spent more time on the social media platforms compared to the married citizens who have spent more time with their family; (4) If targeted citizens are very worried regarding the impact of the governmental measures, then as a result of the adopted measures they felt happy very rarely. The variables of the research were the age, gender, education, income and the relationship status.

In the third stage, we prepared the questionnaire for the survey and identified the online platforms for launching it. The questionnaire was created in Google Forms and consisted of 19 questions, including 18 questions with closed answer and one question with open answer. Five questions included the variables, which contributed to the differentiation of the answers, and 14 questions were in direct connection with the purpose, the specific objectives and the hypothesis of the research. There were two main types of periods in which the Romanian government decided the measures against SARS - COV 2 virus: (1) emergency period - lockdown and (2) alert period - since May 2020.

In the fourth stage, we determinated the sample size of the research. Our objective was to have a representative sample for Bucharest. According to the National Institute of Statistics, on $1^{\text {st }}$ of July 2019 , there were 655,619 people aged between 19 and 40 years old living in Bucharest. The participants were recruited mainly by age for the research. This is a segment of the population with a higher degree of psychological vulnerability, in the context created by the COVID-19 pandemic. The questionnaire was distributed online, on Facebook groups with people living in all the 6 districts of Bucharest and each person in the target age category had the opportunity to take part in the study. The sample size was established taking into account the total population and the level of accuracy using the formula 1 proposed by Androniceanu (2017, p. 71):

$$
n=\frac{N}{1+N(e)^{2}},=\frac{655,619}{1+655,619(0,05)^{2}}=399,75=>\text { at least } 400 \text { respondents }(1)
$$

Therefore, there were necessary at least 400 respondents for the research to be representative, and the survey was completed by 421 respondents. The sample structure by age is presented in Figure 1.

Figure 1: The sample structure by age

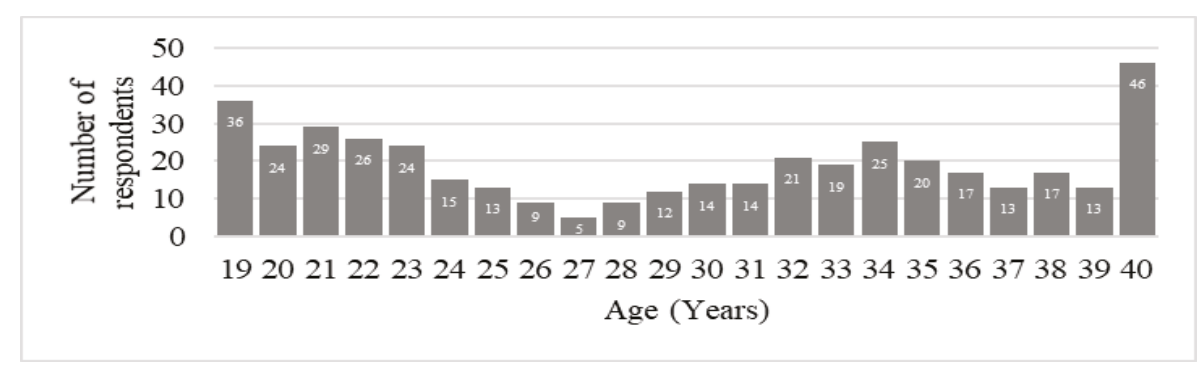

Source: authors

112 Central European Public Administration Review, Vol. 19, No. 1/2021 
Figure 1 shows that the study involved people from each targeted age, but the majority of respondents (10,92\%) are 40 years old.

In the fifth stage, we centralized and analyzed the data based on specific correlations and a model of multiple regression. The multiple regression model shows the level of trust in the measures issued by the governmental authorities and the level of trust in the information transmitted by them in the context of COVID-19 pandemic. The model reflects the influence over the extent to which the targeted citizens complied with the imposed measures.

\section{Main results, analysis and discussion}

This research confirms that the measures taken by the Romanian Government and the local administrative authorities of Bucharest had a significant social and psychological impact on the population included in our research. These effects are presented in Figure 2.

Figure 2: Psychological and social impact generated by the governmental measures

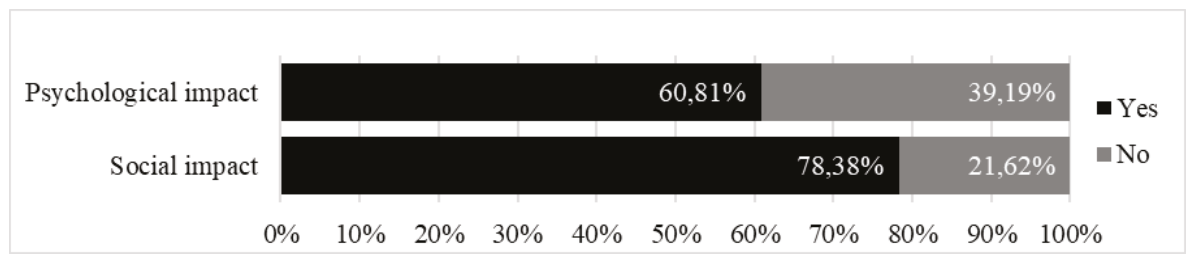

Source: authors

Figure 2 illustrates that the measures endorsed by the governmental authorities were affecting psychologically and socially the majority of the respondents. The social impact was the strongest, $78,38 \%$ of respondents being affected from this point of view. The people could not interact as much as before with other people and the measures adopted such as maintaining the physical distancing, restricting people's mobility and closing the restaurants, the cafes or the cinemas are just some of the factors which contributed to a high social impact. The psychological impact cannot be ignored either, because $60,81 \%$ of respondents were affected from this point of view. The measures adopted by the authorities determined people to feel more anxious, bored, depressed. Furthermore, people declared to be happy, relaxed or calm rarely or very rarely during the COVID-19 pandemic.

We also followed the targeted citizens' level of confidence in the information transmitted and in the measures adopted by the public authorities in the context of COVID-19 pandemic. This aspect is presented in Figure 3. 
Figure 3: The level of confidence of the targeted citizens

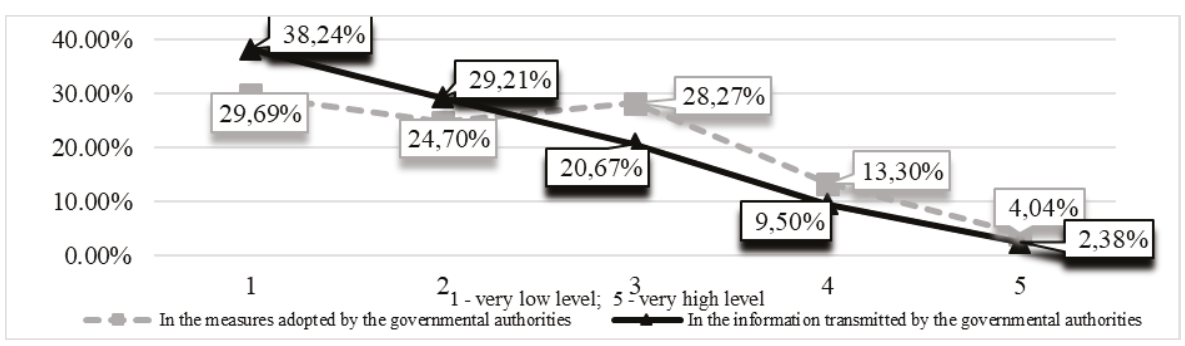

Source: authors

Figure 3 shows obviously negative effects. Most of the respondents had a very low level of confidence and just few people had a very high level of trust both in information transmitted and in measures adopted by public authorities. Regarding the level of trust in information transmitted, just 2,38\% of respondents had a very high level while $38,24 \%$ proved a very low level of it. The level of trust in the information transmitted was identified as a negative effect because $67,45 \%$ of respondents declared a level of trust placed under the medium level (low and very low level) while just 11,88\% declared a positive level of trust (high and very high level). This distrust was determinated by many factors including the authority's communication strategy (for example: contradictory information) or insufficiently explained information (medical or related restrictions). Also, the level of trust of the targeted citizens in the measures adopted by the governmental authorities was identified as a negative effect because $54,39 \%$ of respondents were having a level of trust placed under the minimum level (low and very low level) while just 17,34\% were having a positive level of trust (high and very high level). However, there was a positive aspect because the proportion of those who had an average level of confidence in the measures adopted by Government was higher. Though, just $4,04 \%$ of respondents had a high level of confidence in the measures adopted by the authorities, however their percentage is bigger than the high level of confidence in the information transmitted by the authorities where only $2,38 \%$ of respondents had a very high level of trust. Even if the level of confidence is predominantly negative, $51,10 \%$ of respondents followed in a very large extent the measures decided by the Romanian Government.

The measures adopted by the Romanian Government had a significant psychological and social impact. According to our research results, some of the citizens were affected by the measures of the alert period and the others felt problems as an effect of the measures adopted by the government during the emergency period, when the restrictions of lockdown were stronger. In Romania, Government, Ministry of Internal Affairs or other administrative institutions, such as National Committee for Emergency Situations took the measures to limit the spread of the SARS-CoV-2 virus, by adopting decisions, emergency ordinances or military ordinances. So, the measures that can be seen in Table 1 during the alert period are specified in Decision no. 394/18 May 2020 of the Romanian Government, Decision no. 24/14 May 2020, De- 
cision no. 30/16 June 2020, Decision no. 45/14 September 2020 of the National Committee for Emergency Situations. The measures that can be seen in Table 1 during the emergency period are specified in the Military Ordinance no/18 March 2020, Military ordinance no. 2/ 21 March 2020, Military ordnance no. 3/24 March 2020 of the Ministry of Internal Affairs and Decision no. 9 of 10.03.2020 of the Technical-Scientific Support Group on the management of highly contagious diseases in Romania tacitly approved by the National Committee for Special Emergency Situations by Decision no on 11.03.2020. As can be seen in the table 1, there were citizens who were affected by the measures taken by the government in both periods.

Table 1: Governmental measures and their impact on the targeted citizens

\begin{tabular}{|c|c|c|c|c|c|c|c|c|}
\hline \multirow{3}{*}{$\begin{array}{l}\text { Governmental measures } \\
\text { adopted in both periods } \\
\text { (emergency state and } \\
\text { alert state) during } \\
\text { March - December } 2020\end{array}$} & \multicolumn{8}{|c|}{ Period } \\
\hline & \multicolumn{2}{|c|}{$\begin{array}{l}\text { Emergency } \\
\text { state }\end{array}$} & \multicolumn{2}{|c|}{ Alert state } & \multicolumn{2}{|c|}{$\begin{array}{l}\text { Both types of } \\
\text { states }\end{array}$} & \multicolumn{2}{|c|}{$\begin{array}{l}\text { It is not the } \\
\text { case }\end{array}$} \\
\hline & $\begin{array}{l}\text { No. of } \\
\text { respon- } \\
\text { dents }\end{array}$ & $\%$ & $\begin{array}{l}\text { No. of } \\
\text { respon- } \\
\text { dents }\end{array}$ & $\%$ & $\begin{array}{l}\text { No. of } \\
\text { respon- } \\
\text { dents }\end{array}$ & $\%$ & $\begin{array}{l}\text { No. of } \\
\text { respon- } \\
\text { dents }\end{array}$ & $\%$ \\
\hline $\begin{array}{l}\text { Maintaining physical dis- } \\
\text { tancing. }\end{array}$ & 57 & 13,53 & 45 & 10,68 & 123 & 29,21 & 196 & 46,55 \\
\hline Imposing of the quarantine. & 107 & 25,41 & 46 & 10,92 & 128 & 30,40 & 140 & 33,25 \\
\hline Imposing of the isolation. & 76 & 18,05 & 38 & 9,02 & 112 & 26,60 & 195 & 46,31 \\
\hline $\begin{array}{l}\text { Restricting people's move- } \\
\text { ment outside of their } \\
\text { houses. }\end{array}$ & 122 & 28,97 & 48 & 11,40 & 162 & 38,47 & 89 & 21,14 \\
\hline $\begin{array}{l}\text { Closing restaurants, terrac- } \\
\text { es, cafes. }\end{array}$ & 49 & 11,63 & 57 & 13,53 & 173 & 41,09 & 142 & 33,72 \\
\hline $\begin{array}{l}\text { Closing cultural, scientific, } \\
\text { artistic, religious, sportive } \\
\text { and entertainment activ- } \\
\text { ities. }\end{array}$ & 60 & 14,25 & 53 & 12,58 & 180 & 42,75 & 128 & 30,40 \\
\hline $\begin{array}{l}\text { Holding university classes } \\
\text { exclusively online. }\end{array}$ & 36 & 8,55 & 37 & 8,78 & 171 & 40,61 & 177 & 42,04 \\
\hline Working from home. & 32 & 7,60 & 37 & 8,78 & 84 & 19,95 & 268 & 63,65 \\
\hline
\end{tabular}

Source: authors

Table 1 contains the majority measures which affected the people both psychologically and socially. According to our research results there is a small number of people who did not feel the impact of these measures. However, more than half of respondents were affected by six of the eight measures including both those who felt the effects only in one of the periods (emergency or alert period) and those who felt the effect during both periods. The citizens felt the impact more in the emergency period than in the alert, but 
Armenia Androniceanu, Doina-Mihaela Marton

Central European Public Administration Review, Vol. 19, No. 1/2021 
The Psychosocial Impact of the Romanian Government Measures on the Population During the COVID-19 Pandemic 
Table 3: Targeted citizen's behavioral changes generated by the governmental measures

\begin{tabular}{|l|r|r|}
\hline \multicolumn{1}{|c|}{ Behavioral changes } & $\begin{array}{r}\text { Number of } \\
\text { respondents }\end{array}$ & Percentage \\
\hline Buying more things online. & 262 & $62,23 \%$ \\
\hline Increased attention to personal care and hygiene. & 250 & $59,38 \%$ \\
\hline More cautious in interactions with other people. & 235 & $55,82 \%$ \\
\hline Eating more. & 187 & $44,42 \%$ \\
\hline Sleeping more. & 164 & $38,95 \%$ \\
\hline Working more. & 150 & $35,63 \%$ \\
\hline Reading more. & 101 & $23,99 \%$ \\
\hline Smoking more. & 93 & $22,09 \%$ \\
\hline Drinking more. & 56 & $13,30 \%$ \\
\hline Doing more workouts. & 52 & $12,35 \%$ \\
\hline No behavioral changes. & 24 & $5,70 \%$ \\
\hline Others. & 8 & $1,90 \%$ \\
\hline
\end{tabular}

Source: authors

According to Table 3, from over $50 \%$ of respondents there were identified just three behavioral changes. Public authorities restricted the mobility of the people and imposed a certain schedule or specific reasons to be able to leave their houses. Besides these, the fear of getting the virus or the fear of spreading the virus determined people to stay longer in their homes. Therefore, in order to respect the measures and to be relaxed, $62,33 \%$ of respondents started buying products online and $55,82 \%$ of them started to be more careful in their interactions with other people. Also, $59,38 \%$ of respondents started to be more careful to their personal care and hygiene which is a positive change. Through the behavioral changes mentioned by the respondents, we find "getting annoyed more easily", "going to therapy", "insomnia", "waking up early", "judging harder and removing close people" or "eating very rarely".

The psychological effects generated by the measures issued by the governmental authorities were another aspect followed through the research. The psychological effects and their impact are presented in Figure 5. 
Figure 5: Main psychological effects generated by the governmental measures (number of respondents)

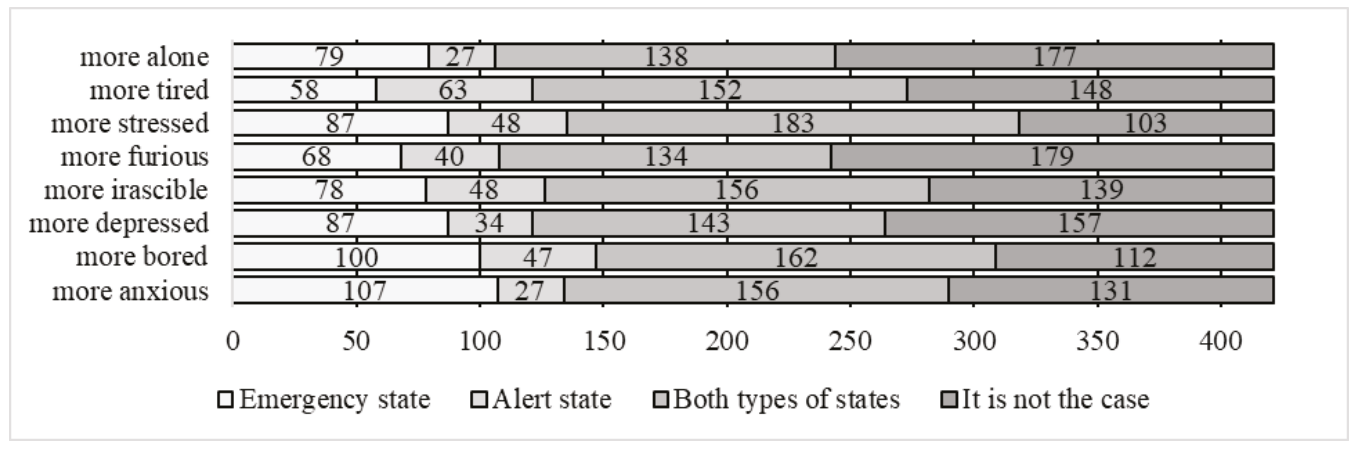

Source: authors

Figure 5 illustrates that all the psychological effects followed through the research have been felt by over $50 \%$ of respondents. This issue demonstrates that the measures adopted by the Government had a huge psychological impact over the targeted citizens. Since the COVID-19 pandemic has started, $73,40 \%$ were felt more bored; $66,99 \%$ more irascible and $64,85 \%$ were felt more tired. Also, the level of depression, anxiety, loneliness or stress has increased, considering the fact that from the beginning of the pandemic, $75,53 \%$ of respondent have felt more stressed; $68,88 \%$ more anxious; $62,71 \%$ more depressed and $57,96 \%$ have felt more alone. If we are talking about the impact on types of states, we can see that there were people affected by the measures only in the emergency state or people affected only in the alert state. The psychological effects were felt by the citizens more in the emergency state than in the alert state, but the majority of the respondents have felt these psychological effects during the emergency state and alert state. So, in both types of states, $37,05 \%$ of targeted citizens have felt more anxious; $38,49 \%$ more bored; $33,97 \%$ more depressed; $37,05 \%$ more irascible; $31,83 \%$ more furious; $43,46 \%$ of them have felt more stressed; $36,10 \%$ more tired and $32,79 \%$ of respondents have felt more alone.

In order not to feel the impact so strongly, the citizens performed some activities to help themselves in this way. These activities are presented in the Figure 6. 
Figure 6: Activities performed by the targeted citizens not to feel the impact so strongly (number of respondents)

\begin{tabular}{|c|c|c|c|c|}
\hline \multirow{2}{*}{$\begin{array}{l}\text { Listening to music } \\
\text { Participating in online classes and workshops }\end{array}$} & \begin{tabular}{l|l|}
34 & 19 \\
\end{tabular} & 296 & & 72 \\
\hline & \begin{tabular}{l|l|}
35 & 37 \\
\end{tabular} & \multicolumn{3}{|c|}{261} \\
\hline Visinting museums online & \multicolumn{2}{|l|}{\begin{tabular}{|l|l|l|l|}
26 & 17 & 18 & \\
\end{tabular}} & 360 & \\
\hline Learning a new foreign language & \begin{tabular}{l|l|l}
30 & 25 & 45 \\
\end{tabular} & \multicolumn{2}{|c|}{321} & \\
\hline Online communication with others & \begin{tabular}{l|l|}
53 & 20 \\
\end{tabular} & \multicolumn{2}{|l|}{251} & 97 \\
\hline Cooking & 28 & \multicolumn{2}{|l|}{188} & 37 \\
\hline Doing sportive exercices & 48 & \multicolumn{2}{|l|}{119} & 179 \\
\hline Watching movies/series & 22 & \multicolumn{2}{|c|}{262} & 67 \\
\hline \multirow[t]{2}{*}{ Reading } & 37 & \multicolumn{2}{|l|}{182} & 28 \\
\hline & 100 & 200 & 300 & 400 \\
\hline \multicolumn{5}{|c|}{$\square$ Alert state $\square$ Both types of states } \\
\hline
\end{tabular}

\section{Source: authors}

Figure 6 illustrates that in order not to feel the impact of the measures so strongly, the citizens have undergone 6 out of 9 activities in this regard. Since the beginning of the pandemic, the top three activities that helped them to pass more easily over it were watching movies/series $(84,09 \%$ of respondents), listening to music (82,90\% of respondents) and communicating with the loved ones through the social media platforms (76,96\% of respondents). During the emergency state, most of the citizens were doing workouts at home $(17,81 \%), 17,56 \%$ were reading and $16,62 \%$ of them were watching movies/series. The least developed activity in emergency state was visiting museums online, just $6,17 \%$ of respondents doing this activity. As we can see in Figure 6, in the alert state not many respondents were developing activities to decrease the impact of the measures. However, in the alert state, most of the respondents were doing home workouts, representing a percentage of $22,40 \%$. As in the emergency state, the fewest respondents (just 4,03\%) were visiting museums online in the alert state too. These activities helped the citizens more in the emergency state than in the alert state, though the majority of the respondents have been doing these activities during both types of states. For example, the top three activities practiced by the citizens to pass more easily over the impact of the measures imposed by the authorities have been listening to music (70,30\%), watching movies/series $(62,23 \%)$ and $59,61 \%$ of respondents have been communicating through the social media platforms with their loved ones.

Also, we wanted to identify if the level of trust in the measures adopted by governmental authorities and the level of trust in the information transmitted by them in the context of COVID-19 pandemic had an influence over the extent to which the targeted citizens complied with the imposed measures. 
To identify this aspect, we generated a multiple regression model, which can be found in table 4.

Table 4: Multiple regression model

SUMMARY OUTPUT

\begin{tabular}{ll}
\hline Regression Statistics & \\
\hline Multiple R & 0,324449231 \\
R Square & 0,105267304 \\
Adjusted R Square & 0,100986286 \\
Standard Error & 0,844373967 \\
Observations & 421 \\
\hline
\end{tabular}

\begin{tabular}{llllll} 
ANOVA & \multicolumn{1}{l}{ SS } & MS & $F$ & Significance $F$ \\
\hline Regression & 2 & 35,06276 & 17,53138 & 24,58932 & $8,01496 \mathrm{E}-11$ \\
Residual & 418 & 298,0204 & 0,712967 & & \\
Total & 420 & 333,0831 & & & \\
\hline
\end{tabular}

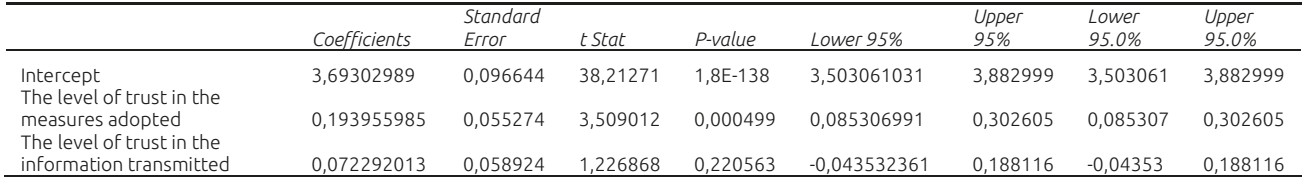

Source: authors

As we can see in table 4, the standard error of this regression is $0,844373967$. Observations represent the number of the respondents with valid answers $(421)$. R Square $(0,105267304)$ represents the coefficient of determination, so, $10,52 \%$ of dependent variable (the degree to which the citizens complied with the measures imposed by the authorities) is explained by the independent variables (the level of trust in the measures adopted and the level of trust in the information transmitted by the governmental authorities), the difference being explained by other factors. Adjusted R Square $(0,100986286)$ represents the corrected value of $\mathrm{R}$ Square and it is used to combat (at least partially) the repercussion caused by the increase of R2 at the same time as the independent variable. Significance $F$ is an indicator which, depending on the 0,05 threshold, demonstrates whether the regression is relevant or not for the purpose of which it was formed. In our case, the Significance F's value is $8,01496 \mathrm{E}-11(0,00000000000801496<0,05)$, so, the regression is statistically relevant. The independent variable relating to the level of trust in the measures adopted shows that the dependent variable is changing with 0,193955985 when the independent variable changes with one unit. In addition, the dependent variable is changing with 0,072292013 when the independent variable relating to the level of trust in the information transmitted changes. P-value for intercept is $1,8 \mathrm{E}-138<0,05$, so, the indicator is statistically relevant. P-value for the level of trust in the adopted measures is $0,000499<0,05$, so, the indicator is statistically relevant, and the P-value for the level of trust in the information transmitted is $0,220563>0,05$, so, the in- 
dicator is not statistically relevant. So, the regression equation is: the degree to which the citizens complied with the measures imposed by the authorities $=3,69302989+0,193955985$ * the level of trust in the measures adopted + 0,072292013 * the level of trust in the transmitted information.

Through the research, we wanted to identify the impact of the measures over the targeted citizens, but we also wanted to identify some measures that, from the citizens' perception, would have had a lower impact over them. So, in the survey we introduced one question with open answer, so that citizens can express their point of view. It was a difficult process because respondents could answer and express in their own way. Even so, all of the 421 answers were grouped and analyzed by us in categories such as "communication of public authorities and media", "keeping the HoReCa industry open", "kindergartens, schools and faculties open", "sustaining the medical system", "adoption of another management model of the situation". The most relevant measures identified in the answers of the respondent are specified in table 5.

Table 5: The most relevant measures that, from the citizens' perception, would have a lower impact over them

\begin{tabular}{|c|c|}
\hline $\begin{array}{l}\text { Number } \\
\text { of the } \\
\text { measure }\end{array}$ & $\begin{array}{l}\text { Measures which, according to the targeted citizens, would of had a reduced } \\
\text { social and psychological impact over them }\end{array}$ \\
\hline 1. & $\begin{array}{l}\text { A communication strategy more transparent, clearer and understandable to the gen- } \\
\text { eral public, including the information regarding the restrictions and the medical ones. }\end{array}$ \\
\hline 2. & $\begin{array}{l}\text { More consistent statements from the authorities. The information provided should } \\
\text { have been more optimistic, presenting more often the positive aspects of this pan- } \\
\text { demic, for example, the medical students who volunteered and helped the Public } \\
\text { Health Directions or the presentation of the number of cured cases, not only of the } \\
\text { large number of infections or deaths. }\end{array}$ \\
\hline 3. & Media should not have been so aggressive in transmitting the information. \\
\hline 4. & $\begin{array}{l}\text { Like government and local authorities, media should have presented more objectively } \\
\text { the situation, without alarming and panicking the population. }\end{array}$ \\
\hline 5. & Keeping the HoReCa industry opened, with strict rules. \\
\hline 6. & $\begin{array}{l}\text { More efficient, faster and more logical organization of the educational system. Kin- } \\
\text { dergartens, schools and universities being opened and classes being held offline, with } \\
\text { strict rules or in a hybrid system (online, offline). }\end{array}$ \\
\hline 7. & $\begin{array}{l}\text { Stricter measures: rigorous controls to ensure that the entire population respects the } \\
\text { measures for limiting the spread of the virus, higher fines for non-compliance or even } \\
\text { a global lockdown for } 2 \text { weeks. }\end{array}$ \\
\hline 8. & Adopting the Swedish model of crisis management. \\
\hline 9. & $\begin{array}{l}\text { More efficient, faster and more logical organization of the medical system. Measures } \\
\text { that facilitate the access of sick citizens who are not infected with the SARS-CoV-2 } \\
\text { virus to the medical system. Facilitating mental health services in the online environ- } \\
\text { ment and the existence of settled psychological counseling activities. }\end{array}$ \\
\hline 10. & Consulting citizens on the measures to be implemented. \\
\hline
\end{tabular}

Source: authors 
Table 5 presents the most relevant measures recommended by the citizens. The main measure was improving the communication strategy. The majority of the respondents were specifying that they would have implemented a better communication strategy. They would have adopted a more transparent, clearer, correct, efficient and more explicit strategy. They would have transmitted positive information (number of cured people, for example), not just the negative ones (number of deaths, for example). In addition, the respondents were specifying that the media played an important role because a lot of aggressive news was transmitted through it, and the drama in every news journal has led the population to fear and depression. Even if at the beginning of pandemic, the number of confirmed cases was low, the people were very scared because of the news and information transmitted by the authorities and media, and at 10,000 confirmed cases per day, people started not to care anymore because they got used to the panic.

This research had four hypotheses, two of them were validated and two invalidated. First hypothesis was invalidated because just $46,56 \%$ of the respondents would have respected more the measures adopted to limit the spread of SARSCoV-2 virus if they had been consulted about the way the virus regarded them. With reference to the second hypothesis, $32,77 \%$ of respondent felt more bored as a result of closing restaurants, terraces and cafes compared to those $22,32 \%$ respondents who felt more bored as a result of the physical distancing, so, the second hypothesis was validated. Of the single respondents, $75,75 \%$ of them spent more time on the social media platforms compared to the married respondents, $77,85 \%$ of them spent more time with their families. As a result, although the percentages are very close, the third hypothesis was invalidated. In addition, $15 \%$ of respondents mentioned that they are very worried regarding the impact of the governmental measures. Of the $15 \%$, no respondent felt happy very often; $7,93 \%$ of respondents felt happy often; $20,63 \%$ of respondents felt happy rarely; $38,09 \%$ of respondents felt happy very rarely, and $33,33 \%$ of them never felt happy because of the measures adopted by the public authorities. As a result, the fourth hypothesis was validated.

The main limitation of the research was the non-inclusion of the population under 19 years and over 40 years old in the research base and in the sample size. In addition, another limitation of the research was the reduced number of the governmental measures and the reduced number of the psychological and social effects. Considering also the fact that the survey was applied online, we did not have direct contact with the respondents, so we could not detail various information that would have been valuable for our research (for example, the measures proposed by the citizens).

We intend to continue this study by expanding the research base and the sample size in order to have a national representativeness for Romania. To achieve this goal, we will diversify our research tools in order to highlight much better the influence of the measures adopted in the context of COVID-19 pandemic on the Romanian population. We want the results of this study to be useful, so we intend to identify the Romanian public authorities' perception regard- 
ing the results of the study. In this way, we think that public authorities will become aware of the actions' impact during the pandemic and they could improve the strategies and the public policies for a better functioning and organization of the administrative and health system of Romania.

\section{Conclusions}

This research was concluded to identify the impact of the governmental measures adopted in the context of COVID-19 pandemic on citizens aged between 19 and 40 years living in Bucharest, the capital of Romania. The results showed both positive and negative conclusions, and some of them were completely unexpected. Although the adopted measures had both psychological and social impact on targeted citizens, it was interesting to find out that the social impact $(78,38 \%)$ was much stronger than the psychological one $(60,81 \%)$. The public authorities suspended certain areas of activity, so people could no longer go out with friends and loved ones to socialize and have fun as they were used to do. The physical distancing separated the people, affecting the human and social relations between them. In the same time, it was interesting to find out that more than half of the respondents felt all the social and psychological effect followed through the research. This shows us that the imposed measures had a strong impact on the populations, and their effects will be clearly felt in the long-term. The return to "old normality" will be a long and hard process, and it will be influenced by the social and psychological effect generated by the adopted measures.

Another conclusion resulting from the research refers to the fact that although not all measures had a major psychological and social impact on the respondents from Bucharest, however, six of eight measures affected more than half of them. All these measures generated changes in respondents' behavior. From the beginning of the pandemic until now, people are buying more things online; they are paying much more attention to their personal care and hygiene and they are much more cautious about the people around them. The citizens mentioned different measures that, in their perception, would have had a lower impact over them, compared to those imposed by the public authorities. Although, some of them were identified in various forms by many respondents. The communication between governmental authorities and citizens was a problem in respondents' opinion; so, most of them would have preferred the existence of a more efficient communication strategy. They would have preferred the information to be disseminated in a more positive and less alarming way. The media played an important role as well. Through the media, excessive and aggressive news was disseminated with information that alarmed the population. In addition, the citizens were considering that it should have been allowed the HoReCa industry (Hotels, Restaurants, Cafes) functioned but with strict rules and in this way people could still go out to socialize. At the same time, kindergartens, schools or universities should have remained on offline teaching system, with strict rules. The online teaching system made the educational process in Romania diffi- 
cult, given that many families cannot offer the appropriate devices and the right infrastructure to their children needed to attend online classes. These are just some of the problems citizens would have improved so that the impact of the measures would not have become so strong. Another conclusion refers to the fact that the level of trust in the information transmitted by the authorities is not a variable which can influence the extent to which citizens comply with the measures imposed by the governmental authorities. This result is mainly determinate by the fact that the citizens perceived as defective the entire communication and coordination process of the central and local authorities during the pandemic period analyzed.

The research revealed also some positive effects of the measures, like the fact that the respondents spent more time with their families. However, the negative effects are worse. They have affected largely both the mental health of the population and the social environment, and the effects will be felt in the long-term. After the end of the pandemic, a new crisis will certainly appear in Romania, so the central government and local authorities should start early to identify some actions to reduce the psychological and social effects of the COVID-19 pandemic on the Bucharest population' health. 


\section{References}

Androniceanu, A. (2017). Fundamente privind elaborarea unei lucrări științifice. Bucharest: Editura Universitară.

Androniceanu, A. (2020). Major structural changes in the EU policies due to the problems and risks caused by COVID-19. Administratie si Management Public, 34, pp. 137-149. doi: 10.24818/amp/2020.34-08.

Akat, M. and Karataş, K. (2020). Psychological Effects of COVID-19 Pandemic on Society and Its Reflections on Education. Turkish Studies, 15(4), pp. 1-13. doi: $0.7827 /$ TurkishStudies.44336.

Amiri, M., Pagheh, B. and Amiri, M. (2020). The impact of the coronavirus crisis on human social life. Conference: Online meeting related to the COVID-19 crisis. Iran. doi: 10.13140/RG.2.2.32004.55683.

Arpaci, I., Karataş, K. and Baloğlu, M. (2020). The development and initial tests for the psychometric properties of the COVID-19 Phobia Scale (C19P-S). Personality and Individual Differences, 164, pp. 1-6. doi: 10.1016/j. paid.2020.110108.

Arpaci, I. et al. (2020). Analysis of Twitter Data Using Evolutionary Clustering during the COVID-19 Pandemic. Computers, Materials \& Continua, 65(1), pp. 193-204. doi: 10.32604/cmc.2020.011489.

Ballou, S., Gray, S., and Palsson, O. S. (2020). Validation of the Pandemic Emotional Impact Scale. Brain Behav Immune Health, 9, pp. 1-6. doi: 10.1016/j.bbih.2020.100161.

Belas, J. et al. (2020). Selected Factors of SMEs Management in the Service Sector. Journal of Tourism and Services, 21(11), 129-146. doi:10.29036/jots. v11i21.215.

Besenyő, J. and Kármán, M. (2020). Effects of COVID-19 pandemy on African health, poltical and economic strategy. Insights into Regional Development, 2(3), pp. 630-644. doi: 10.9770/IRD.2020.2.3(2).

Bo, H.-X. et al. (2020). Posttraumatic stress symptoms and attitude toward crisis mental health services among clinically stable patients with COVID-19 in China. Psychological Medicine, pp. 1-2. doi: 10.1017/S0033291720000999.

Carrasco Sierra, A. et al. (2020). Successful Management System by a Metalworking Mexican Company During Covid-19 Situation. Analysis Through a New Index (Case Study). International Journal of Entrepreneurial Knowledge, 8(2), pp. 42-55. doi: 10.37335/ijek.v8i2.116.

Chehabeddine, M. and Tvaronavičienè, M. (2020). Securing regional development. Insights into Regional Development, 2(1), pp. 430-442. doi: 10.9770/IRD.2020.2.1(3).

Cullen, W., Gulati, G. and Kelly B.D. (2020). Mental health in the COVID-19 pandemic. QJM: An International Journal of Medicine, 113(5), pp. 311-312. doi: 10.1093/qjmed/hcaa110.

Davulis, T., Gasparènienè, L. and Raistenskis, E. (2021). Assessment of the situation concerning psychological support to the public and business in the extreme conditions: case of Covid-19. Entrepreneurship and Sustainability Issues, 8(3), pp. 308-322. doi: 10.9770/jesi.2021.8.3(19).

Decision no. 9 of 10.03 .2020 of the Technical-Scientific Support Group on the management of highly contagious diseases in Romania tacitly approved by the National Committee for Special Emergency Situations by Decision no on 11.03.2020. 
Dobrowolski, Z. (2020). After COVID-19. Reorientation of Crisis Management in Crisis. Entrepreneurship and Sustainability Issues 8(2), pp. 799-810. doi: 10.9770/jesi.2020.8.2(48)

Haleem, A., Javaid, M. and Vaishya, R. (2020). Effects of COVID-19 pandemic in daily life. Current Medicine Research and Practice, pp. 78-79. doi: 10.1016/j. cmrp.2020.03.011.

Hu, W. et al. (2020). COVID-19 outbreak increased risk of schizophrenia in aged adults. ChinaXiv. doi: 10.12074/202003.00003.

Huang, Y. and Zhao, N. (2020). Generalized anxiety disorder, depressive symptoms and sleep quality during COVID-19 outbreak in China: a web-based cross-sectional survey. Psychiatry Research, 288, pp. 1-6. doi: 10.1016/j. psychres.2020.112954.

Korauš, A., Kaščáková, Z. and Felcan, M. (2020). The impact of ability-enhancing HRM practices on perceived individual performance in IT industry in Slovakia. Central European Journal of Labour Law and Personnel Management, 3 (1), 33-45. doi: 10.33382/cejllpm.2020.04.03.

Liu, M. et al. (2020). Modelling the evolution trajectory of COVID-19 in Wuhan, China: experience and suggestions. Public Health, 183, pp. 76-80. doi: 10.1016/j.puhe.2020.05.001.

Ministry of Internal Affairs (2020). Military Ordinance no. 1/18 March 2020 regarding some first aid measures concerning crowds and the cross-border movement of goods, published in the Official Journal of Romania, Part I, no. 219, from 18 March 2020.

Ministry of Internal Affairs (2020). Military Ordinance no. 2/21 March 2020 regarding measures to prevent the spread of COVID-19, published in the Official Journal of Romania, Part I, no. 232, from 21 March 2020.

Ministry of Internal Affairs (2020). Military Ordinance no. 3/24 March 2020 regarding measures to prevent the spread of COVID-19, published in the Official Journal of Romania, Part I, no. 242, from 24 March 2020.

Morens, D., Folkers, G., and Fauci, A.-S. (2009). What Is a Pandemic? The Journal of Infectious Diseases, 200(7), pp. 1018-1021. doi: 10.1086/644537.

Moyo, N. (2020). Antecedents of employee disengagement amid COVID-19 pandemic. Polish Journal of Management Studies, 22 (1), pp. 323-334.

Mura, L. and Horvath, P. (2015) Some aspects of human resource management. International Multidisciplinary Scientific Conferences on Social Sciences and Arts, Albena, Bulgaria, pp. 863-870.

Naser, A.Y. et al. (2020). The effect of the 2019 coronavirus disease outbreak on social relationships: A cross-sectional study in Jordan. International Journal of Social Psychiatry, pp. 1-8. doi:https://doi.org/10.1177/0020764020966631.

National Committee for Emergency Situations (2020). Decision no. 24/14 May 2020 on approving the establishment of a national alert state and prevention measures and infection control, in the context of the epidemiological situation generated by the SARSCoV-2 virus. Official Journal of Romania, Part I, no. 395, from 15 May 2020.

National Committee for Emergency Situations (2020). Decision no. 30/16 June 2020 on the proposal of some measures necessary to be applied during the alert state for preventing and combating the effects of the COVID-19 pandemic.

National Committee for Emergency Situations (2020). Decision no. 45/14 September 2020 on the proposal to extend the alert and the measures 
necessary to be applied during it to prevent and combat the effects of the COVID-19 pandemic.

National Institute of Statistics. (2020). At<https://insse.ro/cms/: http://statistici. insse.ro:8077/tempo-online/\#/pages/tables/insse-table>, accessed 3 January 2021.

Nosková, M. and Peráček, T. (2019). Termination of employment in the Slovak Republic as a key issue of HR Management. Central European Journal of Labour Law and Personnel Management, 2(2), pp. 44-59. doi: 10.33382/ cejllpm.2019.03.04.

Rathod, S. et al. (2020). Journal Pre-Proof Psychological impact of COVID-19 Pandemic: Protocol and Results of first three weeks from an international cross-section survey - focus on health professionals. Journal of Affective Disorders Reports, 1. doi: 10.1016/j.jadr.2020.100005.

Romanian Government (2020). Decision no. 394/18 May 2020 regarding the declaration of the state alert and the measures to be applied during it to prevent and combat the effects of the COVID-19 pandemic. Official Journal of Romania, Part I, no. 410, from 18 May 2020.

Sawangchai, A. et al. (2020). Effects of COVID-19 on digital learning of entrepreneurs. Polish Journal of Management Studies, 22(2), pp. 502-517.

Sher, L. (2020). The impact of the COVID-19 pandemic on suicide rates. QJM: An International Journal of Medicine, 113(10), pp. 707-712. doi: 10.1093/qjmed/ hcaa202.

Silva Junior, F.J.G.D. et al. (2020). Impact of COVID-19 pandemic on mental health of young people and adults: a systematic review protocol of observational studies. BMJ Open, 10(7), pp. 1-6. doi: 10.1136/ bmjopen-2020-039426.

Singh, J. and Hasan, A. (2020). COVID - 19's Impact on the Society. Electronic Research Journal of Social Sciences and Humanities, 2(1), pp. 168-172. At <https://www.researchgate.net/publication/340769976_COVID_-_19\%27s_ Impact_on_the_Society>, accessed 15 November 2020.

Verma, A. K. and Prakash, S. (2020). Impact of COVID-19 on environment and society. Journal of Global Biosciences, 9(5), pp. 7352-7363. doi: www. mutagens.co.in/jgb/vol.09/05/090506.pdf.

Vidyakant, J. A. and Appasani, B. (2020). nCOVID-19: Social and Economic Impacts. Conference: 1st International Conference-2020 on "COVID-19: Lives and Livelihood". Bhubaneswar: KIIT University. At <https://www. researchgate.net/publication/341349723_nCOVID-19_Social_and_Economic Impacts>, accessed 15 November 2020.

Vlacseková, D. and Mura, L. (2017). Effect of motivational tools on employee satisfaction in small and medium enterprises. Oeconomia Copernicana, 8 (1), pp. 111-130. doi: 10.24136/oc.v8i1.8

Zandi, G. et al. (2020). Supporting role of society and firms to COVID-19 management among medical practitioners. International Journal of Environmental Research and Public Health, 17(21), pp.1-2, 7961.

World Health Organization (2020). Coronavirus disease (COVID-19). At <https:// www.who.int/emergencies/diseases/novel-coronavirus-2019/question-andanswers-hub/q-a-detail/coronavirus-disease-covid-19>, accessed 12 October 2020.

World Health Organization (2021). WHO Coronavirus Disease (COVID-19) Dashboard. At <https://covid19.who.int>, accessed 31 January 2021. 


\section{ANNEXES}

Questionnaire - Study on the impact of governmental measures in the context of the COVID-19 pandemic on the citizens of Bucharest

Question 1: How old are you?

Choose.

Question 2: What is your gender?

Female.

Male.

Question 3: What is the last form of study completed?
Primary studies
Gymnasium studies.
High-school degree.
Bachelor's degree.
Master's degree.
Doctoral studies.
Post-graduate studies.

Question 4: What is your monthly income?

Under 1,000 RON.

Between 1,001 and 2,000 RON.

Between 2,001 and 3,000 RON.

Between 3,001 and 4,000 RON.

Between 4,001 and 5,000 RON.

Over 5,001 RON.

Question 5: What is the current state of your relationship?
O Single.
In a relationship.
$\bigcirc$ Engaged.
Married.
$O$ Divorced.
Widower/widow.

Question 6: Do you consider that the measures adopted by the governmental authorities have contributed to limiting the spread of the SARS-CoV-2 virus in Bucharest?

$$
\begin{aligned}
& \text { Yes. } \\
& \text { No. }
\end{aligned}
$$

Question 7: On a scale of 1 to 5, what is your confidence level: (1 - very low; 5 - very high)

\begin{tabular}{l|c|c|c|c|c|c} 
& 1 & 2 & 3 & 4 & 5 \\
\hline $\begin{array}{l}\text { In the measures adopted by the } \\
\text { governmental authorities }\end{array}$ & $\bigcirc$ & $\bigcirc$ & $\bigcirc$ & $\bigcirc$ & $\bigcirc$ \\
\hline $\begin{array}{l}\text { In the information transmitted by the } \\
\text { governmental authorities }\end{array}$ & $\bigcirc$ & $\bigcirc$ & $\bigcirc$ & $\bigcirc$ & $\bigcirc$
\end{tabular}

Question 8: Do you consider that the governmental measures adopted have had a negative psychological and social impact on you? 


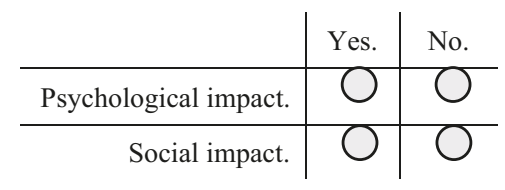

Question 9: How worried are you about the impact that the governmental measures have on you?

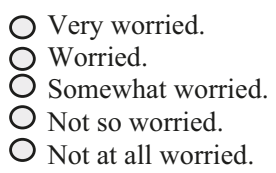

Question 10: Which of the following governmental measures do you consider to have had a psychological and social impact on you? (more options allowed)

\begin{tabular}{l|c|c|c} 
& Emergency state & Alert state & It is not the case \\
\hline Maintaining physical distancing. & $\square$ & $\square$ & $\square$ \\
\hline Imposing of the quarantine. & $\square$ & $\square$ & $\square$ \\
\hline Imposing of the isolation. & $\square$ & $\square$ & $\square$ \\
\hline $\begin{array}{l}\text { Restricting people's movement outside } \\
\text { of their houses. }\end{array}$ & $\square$ & $\square$ & $\square$ \\
\hline $\begin{array}{l}\text { Closing restaurants, terraces, cafes. } \\
\text { religious, sportive and entertainment } \\
\text { activities. }\end{array}$ & $\square$ & $\square$ & $\square$ \\
\hline $\begin{array}{l}\text { Holding university classes exclusively } \\
\text { online. }\end{array}$ & $\square$ & $\square$ & $\square$ \\
\hline $\begin{array}{l}\text { Working from home. } \\
\text { Closing cultural, scientific, artistic, }\end{array}$ & $\square$ & $\square$ & $\square$
\end{tabular}

Question 11: From a psychological point of view, as a result of the governmental measures adopted, you felt: (more options allowed)

\begin{tabular}{l|c|c|c} 
& Emergency state & Alert state & It is not the case \\
\hline More anxious. & $\square$ & $\square$ & $\square$ \\
\hline More bored. & $\square$ & $\square$ & $\square$ \\
\hline More depressed. & $\square$ & $\square$ & $\square$ \\
\hline More irascible. & $\square$ & $\square$ & $\square$ \\
\hline More furious. & $\square$ & $\square$ & $\square$ \\
\hline More stressed. & $\square$ & $\square$ & $\square$ \\
\hline More tired. & $\square$ & $\square$ & $\square$
\end{tabular}

Question 12: As a result of the governmental measures, how often have you felt:

\begin{tabular}{l|l|l|l|} 
Never. & Very rarely. $\mid$ Rarely. & Often. & Very often.
\end{tabular} 


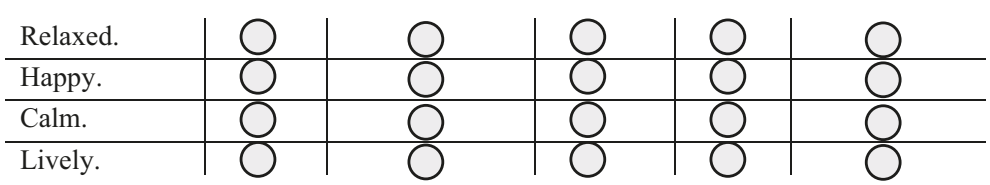

Question 13: From a social point of view, what were the effects of the governmental measures imposed by the authorities on you? (more options allowed)

\begin{tabular}{l|c|c|c} 
& Emergency state & Alert state & It is not the case \\
\hline Change of the lifestyle. & $\square$ & $\square$ & $\square$ \\
\hline Reduced interaction with other people. & $\square$ & $\square$ & $\square$ \\
\hline More time spent on the social media. & $\square$ & $\square$ & $\square$ \\
\hline More time spent in the front of the TV. & $\square$ & $\square$ & $\square$ \\
\hline More time spent with the family. & $\square$ & $\square$ & $\square$
\end{tabular}

Question 14: Which of the following activities helped you get over the restrictions imposed by the authorities? (more options allowed)

\begin{tabular}{l|c|c|c} 
& Emergency state & Alert state & It is not the case \\
\hline Reading. & $\square$ & $\square$ & $\square$ \\
\hline Watching movies/series. & $\square$ & $\square$ & $\square$ \\
\hline Doing sportive exercises. & $\square$ & $\square$ & $\square$ \\
\hline Cooking. & $\square$ & $\square$ & $\square$ \\
\hline Online communication with others. & $\square$ & $\square$ & $\square$ \\
\hline Learning a new foreign language. & $\square$ & $\square$ & $\square$ \\
\hline Visiting museums online. & $\square$ & $\square$ & $\square$ \\
\hline $\begin{array}{l}\text { Participating in online classes and } \\
\text { workshops. }\end{array}$ \\
\hline Listening to music. & $\square$ & $\square$ & $\square$
\end{tabular}

Question 15: What have been the behavioral changes as a result of the governmental measures imposed by the authorities? (more options allowed)

Buying more things online.

Increased attention to personal care and hygiene.

More cautious in interactions with other people.

Eating more.

Sleeping more.

Working more.

Reading more.

$\bigcirc$ Smoking more.

Drinking more.

Doing more workouts.

No behavioral changes.

Others.

Question 16: In your opinion, what measures do you think could have been taken by the governmental authorities in order to have a lower psychological and social impact?

Your answer. 
Question 17: On a scale of 1 to 5, to what extent have you complied with the measures imposed by the governmental authorities?
to a very small extent
$\begin{array}{lllll}1 & 2 & 3 & 4 & 5\end{array}$
Co very small extent
00000
to a very large extent

Question 18: Do you think that you would have complied more with the measures imposed if the governmental authorities had consulted you on them?

Y Yes.

No.

Question 19: Do you think that the quality of your life has worsened as a result of the governmental measures? Yes.

No. 